Vol 1. No 2. Oktober Tahun 2021 e-ISSN : 2798-5466 P-ISSN : 2798-5725

\title{
UPAYA MENINGKATKAN HASIL BELAJAR BAHASA INGGRIS SUBTEMA INTRODUCE MYSELF MELALUI PENERAPAN MODEL PEMBELAJARAN THINK TALK WRITE SISWA KELAS VII B SMPN 1 SUMOWONO SEMESTER 1 TAHUN PELAJARAN 2018/2019
}

\author{
SOFIA KUSTININGSIH \\ SMPN 3 Ambarawa \\ e-mail: sofiakustiningsih84@gmail.com
}

\begin{abstract}
ABSTRAK
Penelitian ini bertujuan untuk mendeskripsikan proses dan hasil belajar siswa kelas VII B SMPN 1 Sumowono Semester 1 Tahun Pelajaran 2018/2019 pada pembelajaran bahasa Inggris subtema Introduce Myself setelah siswa mengikuti pembelajaran dengan model pembelajaran TTW (Think Talk Write). Penelitian ini merupakan penelitian tindakan kelas yang dilakukan secara kolaboratif antara peneliti sebagai guru mata pelajaran Bahasa Inggris dan wali kelas VII B. Tindakan dilaksanakan dalam 2 siklus dengan masing-masing siklus terdiri dari 2 pertemuan. Subjek penelitian adalah siswa kelas VII B SMPN 1 Sumowono Semester 1 Tahun Pelajaran 2018/2019 dengan jumlah siswa sebanyak 31 siswa. Teknik pengumpulan data dalam penelitian ini menggunakan tes, observasi, dan dokumentasi. Validasi data menggunakan teknik triangulasi. Hasil penelitian menunjukkan keaktifan belajar meningkat dari angka 45,16\% atau 14 siswa pada studi awal menjadi 74,19\% atau 23 siswa pada siklus I, meningkat menjadi 93,55\% atau 29 siswa pada akhir siklus II. Adapun penjelasan nilai rata-rata hasil dan ketuntasan belajar yang terus meningkat pada studi awal hanya 63,55 naik menjadi 72,90 pada siklus I, dan 80,32 pada siklus II. Nilai rata-rata pada siklus kedua tersebut sudah memenuhi standar Kriteria Ketuntasan Minimum (KKM) yaitu 75. Ketuntasan belajar sebanyak 8 siswa atau $25,81 \%$ pada studi awal, 48,39\% atau 15 siswa pada siklus I, 28 siswa atau 90,32\% pada siklus II. Ketuntasan belajar sudah mencapai $85 \%$ dari jumlah seluruh siswa sesuai dengan indikator dan kriteria keberhasilan yang telah ditentukan. Dengan demikian dapat disimpulkan bahwa melalui penerapan model pembelajaran TTW (Think Talk Write), efektif untuk meningkatkan hasil belajar siswa kelas VII B SMPN 1 Sumowono Semester 1 Tahun Pelajaran 2018/2019 pada pembelajaran bahasa Inggris subtema Introduce Myself.
\end{abstract}

Kata Kunci: keaktifan, hasil belajar, Think Talk Write

\section{PENDAHULUAN}

Keterampilan siswa kelas VII B SMPN 1 Sumowono Semester 1 Tahun Pelajaran 2018/2019 pada pembelajaran bahasa Inggris subtema Introduce Myself masih merupakan masalah bagi siswa. Dalam proses pembelajaran masih banyak siswa yang mengalami kebingungan dalam mengembangkan kemampuannya dan tidak semua siswa bisa menyelesaikan tugas tersebut dengan baik. Hal ini membuat pencapaian siswa khususnya pada kecakapan menulis khususnya pada subtema Introduce Myself masih rendah. Selain itu, metode pembelajaran yang digunakan kurang variatif, kurang menyesuaikan antara metode dengan materi pokok sehingga tampak monoton (cenderung teoiritis), dan sering menggunakan metode ceramah. Hal ini akan membawa suasana belajar membosankan dan tidak dapat mengembangkan keterampilan bahasa Inggris siswa. Oleh karena itu, agar hasil belajar bahasa Inggris subtema Introduce Myself dapat meningkat, maka seorang guru dituntut menguasai dan menerapkan beberapa model pembelajaran yang ada sehingga pembelajarannya dapat bervariasi dan berpusat pada siswa. Salah satu upaya untuk mengatasi kesulitan belajar siswa dalam pembelajaran bahasa Inggris pada subtema Introduce Myself adalah dengan menerapkan pembelajaran melalui strategi Think Talk Write (TTW).

Zulkarnaini (2011:149) menuliskan pembelajaran Think Talk Write adalah suatu tipe pembelajaran kooperatif yang terdiri dari beberapa anggota dalam satu kelompok yang bertanggung jawab atas penguasaan bagian materi belajar dan mampu mengajarkan materi 
tersebut kepada anggota dalam kelompoknya. Dewa Ayu (2014:3) menuliskan ciri khas yang membedakan model pembelajaran kooperatif tipe TTW dengan model pembelajaran kooperatif lainnya antara lain: siswa dibantu oleh guru dalam mengkonstruksi pengetahuan sendiri sehingga pemahaman konsep siswa menjadi lebih baik. Siswa dapat mengkomunikasikan atau mendiskusikan pemikirannya dengan temannya sehingga siswa saling membantu dan saling bertukar pikiran. Hal ini akan membuat siswa lebih memahami materi yang diajarkan. Selain itu, melatih siswa untuk menulis hasil diskusinya ke dalam bentuk tulisan secara sistematis sehingga siswa akan mampu memahami materi, selanjutnya siswa dapat mengkomunikasikan ide-idenya baik secara lisan maupun tulisan. Pembelajaran dengan model Think Talk Write (TTW) dapat mengembangkan kemampuan siswa dalam bekerja sama bersama temannya, terlibat aktif untuk berpikir, membicarakan idenya dan mendengarkan ide teman, serta menulis apa yang menjadi perbincangan dalam kelompok. Pembelajaran yang membuat siswa aktif akan menumbuhkan suasana kreatif dan menyenangkan dalam belajar.

Seperti yang diungkapkan oleh Desy Ambari (2013:3) "model pembelajaran Think Talk Write dapat menciptakan suasana belajar yang menyenangkan dan bermakna dalam pembelajaran dari hasil penyelidikan, penyimpulan, serta meningkatkan minat dan partisipasi dan daya ingat". Dengan penerapan pembelajaran model TTW dalam penelitian tindakan kelas ini diharapkan dapat meningkatkan keaktifan siswa. Siswa dapat secara nyata merasakan belajar dengan cara baru yang lebih inovatif. Siswa akan belajar menjadi sumber belajar bagi temannya dan memperoleh informasi dari beberapa sumber. Pembelajaran yang menuntut siswa untuk dapat memikirkan materi ajar, membicarakan idenya, dan menulis hasil diskusi bersama teman yang menjadi kesimpulan penemuan masalah yang disajikan guru, dirasa dapat meningkatkan hasil belajar siswa dalam pembelajaran bahasa Inggris. Selain itu, rasa semangat dan kebersamaan siswa dalam belajar dapat ditumbuhkan dengan model pembelajaran TTW.

Berdasarkan penjelasan sebagaimana latar belakang masalah di atas, peneliti meminta bantuan kepala sekolah, dan teman sejawat untuk membantu mengidentifikasi kekurangan dari pembelajaran yang dilaksanakan. Dari hasil diskusi terungkap beberapa masalah yang terjadi dalam pembelajaran, yaitu: (1) siswa jarang mengajukan pertanyaan meskipun guru telah memancing dengan pertanyaan-pertanyaan yang sekiranya siswa belum jelas, (2) siswa kurang semangat, kurang partisipasi, dan kurang tertarik dalam mengikuti pembelajaran bahasa Inggris yang dianggap membosankan dan tidak penting bahkan beberapa siswa mengantuk dan mengobrol dengan teman sebangkunya, (3) bimbingan yang diberikan oleh guru sulit diterima oleh siswa sehingga diharapkan guru harus lebih banyak berkomunikasi dengan siswa, menanyakan hal-hal yang belum dipahami oleh siswa, serta memberi kesempatan kepada siswa untuk bertanya, dan (4) metode pembelajaran yang digunakan guru kurang bervariasi dan cenderung membosankan.

Adapun tujuan dari pelaksanaan perbaikan pembelajaran yang dilaksanakan melalui pelaksanaan penelitian tindakan kelas ini adalah untuk mengetahui bagaimana proses pelaksanaan pembelajaran dan peningkatan hasil belajar dengan menerapkan model pembelajaran Think Talk Write siswa kelas VII B SMPN 1 Sumowono Semester 1 Tahun Pelajaran 2018/2019.

\section{METODE PENELITIAN}

PTK merupakan kegiatan perbaikan pembelajaran yang terdiri dari beberapa rangkaian kegiatan yang saling berkaitan dan berdaur atau siklus dengan empat langkah utama yaitu perencanaan tindakan, pelaksanaan tindakan, observasi, dan refleksi. 
Penjelasan mengenai daur siklus PTK disajikan pada Gambar 1. di bawah ini:

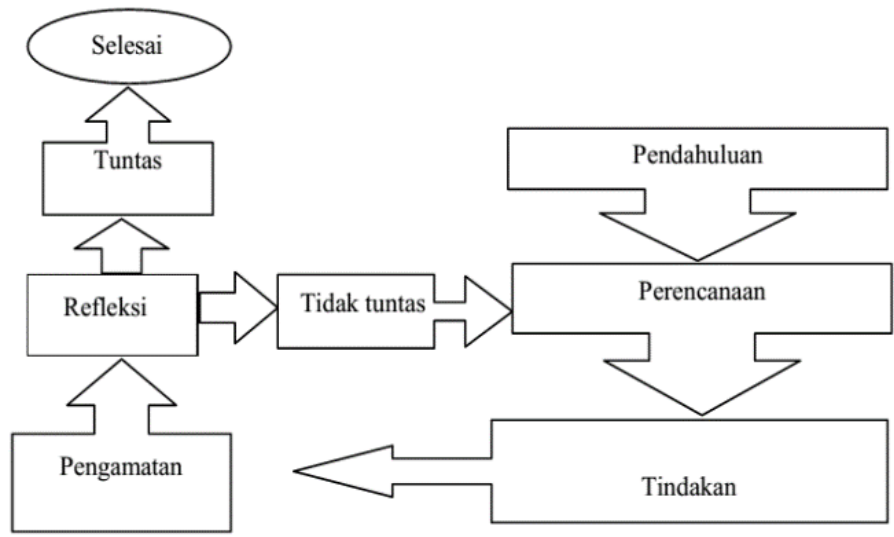

Gambar 1. Daur PTK

(dimodifikasi dari Arikunto, 2006: 46)

Dalam penelitian ini guru melakukan pengumpulan data menggunakan teknik tes, observasi, dan dokumentasi atau teknik triangulasi data. Triangulasi data yaitu mengecek keabsahan (validasi) data dengan mengkonfirmasikan data yang sama dari sumber yang berbeda untuk memastikan keabsahan (derajat kepercayaan). Dari guru dilakukan pada saat pelaksanaan kegiatan model pembelajaran Think Talk Write (TTW) balikan refleksi setelah pelaksanaan tindakan dan dengan data yang dijaring melalui lembar observasi teman guru/sejawat dan kepala sekolah. Sedangkan dari siswa dilakukan melalui tes formatif yang dilaksanakan pada prasiklus, akhir siklus pertama, dan akhir siklus kedua.

\section{HASIL DAN PEMBAHASAN}

\section{Deskripsi Kondisi Awal}

Dalam melaksanakan proses belajar mengajar di kelas VII B SMP N 1 Sumowono banyak masalah yang dihadapi. Hal ini disebabkan proses pembelajaran bahasa Inggris pada subtema Introduce Myself hanya mentransfer konsep-konsep yang termuat dalam buku teks, masih berpusat pada guru, dan kurang memberikan kesempatan kepada siswa untuk membangun pengetahuannya sendiri melalui model pembelajaran TTW. Dari hasil pengamatan peneliti, siswa belum pernah diajarkan untuk berpikir kritis dan mayoritas siswa masih rendah kemampuan pemecahan masalah. Keterampilan diskusi perlu ditanamkan sejak dini karena merupakan dasar yang diperlukan untuk memahami masalah-masalah dalam pembelajaran bahasa Inggris yang dipelajari di kelas. Siswa hanya menuliskan hasil akhirnya saja tanpa memperhatikan proses pengerjaannya. siswa tidak menguraikan tahapan pemecahan masalah seperti memahami masalah, membuat rencana penyelesaian soal, melaksanakan penyelesaian dan mengecek kembali hasilnya. Hal ini disebabkan siswa belum terbiasa menyelesaikan soal sebagaimana peneliti harapkan. Hasil tes formatif pada kondisi awal pembelajaran dijelaskan pada Tabel 1. di bawah ini:

Tabel 1. Rekapitulasi Nilai Tes Formatif Pembelajaran Kondisi Awal

\begin{tabular}{cccccc}
\hline No & Skor & $\begin{array}{c}\text { Jumlah } \\
\text { Siswa }\end{array}$ & Capaian & Persentase & Ket \\
\hline $\mathbf{1}$ & $\geq 86$ & 3 & 270 & 09,68 & $\mathrm{~T}$ \\
$\mathbf{2}$ & $76-85$ & 5 & 400 & 16,13 & $\mathrm{~T}$ \\
$\mathbf{3}$ & $66-75$ & 6 & 420 & 19,35 & $\mathrm{BT}$ \\
$\mathbf{4}$ & $51-65$ & 10 & 600 & 32,26 & $\mathrm{BT}$ \\
$\mathbf{5}$ & $\leq 50$ & 7 & 280 & 22,58 & $\mathrm{BT}$ \\
\hline & Jumlah & $\mathbf{3 1}$ & $\mathbf{1 9 7 0}$ & $\mathbf{1 0 0}$ & - \\
\hline & N. Rata-2 & - & $\mathbf{6 3 , 5 5}$ & - & - \\
& Ketuntasan & - & $\mathbf{2 5 , 8 1}$ & - & - \\
\hline
\end{tabular}


Dari penjelasan Tabel 1. di atas dapat disimpulkan bahwa hasil observasi awal kelas hanya 8 orang yang mendapat nilai nilai $\geq 75$ atau $25,81 \%$ yang mencapai Kriteria Ketuntasan Minimal (KKM), sedangkan 23 orang atau 74,19\% belum mencapai KKM, dengan perolehan nilai rata-rata klasikal sebesar 63,55. Hasil pembelajaran tersebut menunjukkan adanya pembelajaran yang memerlukan penanganan khusus yang akan dilakukan dengan melaksanakan kegiatan penelitian tindakan kelas.

\section{Deskripsi Siklus I}

Pelaksanaan pembelajaran bahasa Inggris pada siklus I menggunakan 4 tahap, yaitu perencanaan, pelaksanaan tindakan, observasi, dan refleksi. Pada tahap perencanaan, pembelajaran dilaksanakan menggunakan model pembelajaran Think Talk Write (TTW. Hasil pelaksanaan tindakan pembelajaran bahasa Inggris dengan menerapkan penggunaan model pembelajaran tipe Think Talk Write (TTW) pada siklus I sebagaimana diuraikan pada Tabel 2. di bawah ini:

Tabel 2. Rekapitulasi Nilai Tes Formatif Pembelajaran Bahasa Inggris pada Siklus I

\begin{tabular}{cccccc}
\hline No & Skor & $\begin{array}{c}\text { Jumlah } \\
\text { Siswa }\end{array}$ & Capaian & Persentase & Ket \\
\hline $\mathbf{1}$ & $\geq 86$ & 3 & 270 & 9,68 & $\mathrm{~T}$ \\
$\mathbf{2}$ & $76-85$ & 12 & 960 & 38,71 & $\mathrm{~T}$ \\
$\mathbf{3}$ & $66-75$ & 9 & 630 & 29,03 & $\mathrm{BT}$ \\
$\mathbf{4}$ & $51-65$ & 6 & 360 & 19,35 & $\mathrm{BT}$ \\
$\mathbf{5}$ & $\leq 50$ & 1 & 40 & 3,23 & $\mathrm{BT}$ \\
\hline & Jumlah & $\mathbf{3 1}$ & $\mathbf{2 . 2 6 0}$ & $\mathbf{1 0 0 , 0 0}$ & - \\
\hline & N. Rata-2 & - & $\mathbf{7 2 , 9 0}$ & - & - \\
& Ketuntasan & - & $\mathbf{4 8 , 3 9}$ & - & - \\
\hline
\end{tabular}

Hasil tes formatif pada siklus pertama sebagaimana tersaji pada Tabel 2. di atas tentang Rekapitulasi Nilai Tes Formatif Pembelajaran Bahasa Inggris materi Introduce Myself pada Siklus I, dapat diterangkan sebagai berikut: nilai rata-rata hasil belajar pada pelaksanaan perbaikan pembelajaran siklus pertama sebesar 72,90. Jumlah siswa yang tuntas belajarnya sebanyak 15 siswa atau sebesar 48,39\% dan yang belum tuntas belajarnya sebanyak 16 siswa atau sebesar $51,61 \%$. Peneliti dan observer menyimpulkan bahwa hasil pengamatan terhadap peningkatan ketuntasan belajar belum mencapai angka di atas $85 \%$ dan nilai rata-rata hasil belajar belum mencapai KKM sebesar 75 sehingga proses perbaikan pembelajaran masih harus dilanjutkan pada siklus II.

\section{Deskripsi siklus II}

Berdasarkan hasil tes formatif dan refleksi pada siklus I, maka pada dua pertemuan yang akan dilaksanakan, peneliti merevisi Rencana Pelaksanaan Pembelajaran (RPP). RPP siklus II difokuskan pada perencanaan langkah-langkah perbaikan atau skenario tindakan yang diharapkan dapat meningkatkan keterampilan siswa dalam pembelajaran. Dalam rencana perbaikan pembelajaran ini peneliti menggunakan model pembelajaran Think Talk Write (TTW). Di samping itu, peneliti juga menyiapkan bahan ajar, lembar kerja siswa (LKS) yang akan digunakan oleh siswa pada proses pembelajaran; instrumen pengumpulan data yaitu lembar tes akhir pembelajaran; dan merencanakan aspek-aspek yang diamati dan dinilai dari pelaksanaan perbaikan pembelajaran, yaitu persiapan, kejelasan materi, pengorganisasian, latihan dan bimbingan, penutup; serta merencanakan kriteria keberhasilan perbaikan pembelajaran. Dalam penelitian ini keberhasilan pembelajaran ditetapkan apabila $85 \%$ dari semua siswa telah mencapai prestasi belajar dengan nilai minimal 75. Hasil tes formatif pada siklus II pembelajaran dijelaskan pada Tabel 3 di bawah ini: 
Vol 1. No 2. Oktober Tahun 2021 e-ISSN : 2798-5466 P-ISSN : 2798-5725

Tabel 3. Rekapitulasi Nilai Tes Formatif Pembelajaran Bahasa Inggris pada Siklus II

\begin{tabular}{ccccccc}
\hline No & Skor & $\begin{array}{c}\text { Jumlah } \\
\text { Siswa }\end{array}$ & Capaian & Persentase & Kriteria & Ket \\
\hline $\mathbf{1}$ & $\geq 86$ & 5 & 450 & 16,13 & $\mathrm{SB}$ & $\mathrm{T}$ \\
$\mathbf{2}$ & $76-85$ & 23 & 1.840 & 74,19 & $\mathrm{~B}$ & $\mathrm{~T}$ \\
$\mathbf{3}$ & $66-75$ & 2 & 140 & 6,45 & $\mathrm{C}$ & $\mathrm{BT}$ \\
$\mathbf{4}$ & $51-65$ & 1 & 60 & 3,23 & $\mathrm{~K}$ & $\mathrm{BT}$ \\
$\mathbf{5}$ & $\leq 50$ & 0 & 0 & 0,00 & $\mathrm{KS}$ & $\mathrm{BT}$ \\
\hline & Jumlah & $\mathbf{3 1}$ & $\mathbf{2 . 4 9 0}$ & $\mathbf{1 0 0}$ & - & - \\
\hline N. Rata-2 & - & $\mathbf{8 0 , 3 2}$ & - & - & - \\
Ketuntasan & - & $\mathbf{9 0 , 3 2}$ & - & - & - \\
\hline
\end{tabular}

Dari Tabel 3. tentang Rekapitulasi Nilai Tes Formatif Pembelajaran Bahasa Inggris Materi Introduce Myself pada Siklus II di atas dapat diterangkan sebagai berikut: nilai rata-rata hasil belajar pada pelaksanaan perbaikan pembelajaran siklus kedua sebesar 80,32. Jumlah siswa yang tuntas belajarnya sebanyak 28 siswa atau sebesar 90,32\%. Jumlah siswa yang belum tuntas belajarnya sebanyak 3 siswa atau sebesar 9,68\%. Oleh karena itu, peneliti bersama-sama dengan observer menyimpulkan bahwa ketuntasan belajar berdasarkan rata-rata nilai tes formatif sudah mencapai angka di atas $85 \%$, dan nilai hasil belajar sudah melebihi KKM sebesar 75, sehingga proses perbaikan pembelajaran dinyatakan berhasil dan tuntas pada siklus II. Secara rinci dapat dilihat perbandingan hasil belajar siswa pada kondisi awal, pada Tabel 4 . di bawah ini:

Tabel 4. Rekapitulasi Hasil Belajar Bahasa Inggris Siswa pada Kondisi Awal, Siklus I, dan Siklus II

\begin{tabular}{ccccccc}
\hline \multirow{2}{*}{ No } & \multirow{2}{*}{ Uraian } & Nilai & \multicolumn{2}{c}{ Siswa Tuntas } & \multicolumn{2}{c}{ Siswa Belum Tuntas } \\
\cline { 3 - 7 } & & Rata-Rata & Frekuensi & \% & Frekuensi & \% \\
\hline $\mathbf{1}$ & Awal & 63,55 & 8 & 25,81 & 23 & 74,19 \\
$\mathbf{2}$ & Siklus I & 72,90 & 15 & 48,39 & 16 & $51,61 \%$ \\
$\mathbf{3}$ & Siklus II & 80,32 & 28 & 90,32 & 3 & 9,68 \\
\hline
\end{tabular}

Untuk memperjelas hasil ketuntasan belajar siswa dapat dilihat pada Grafik 1. diagram batang di bawah ini:

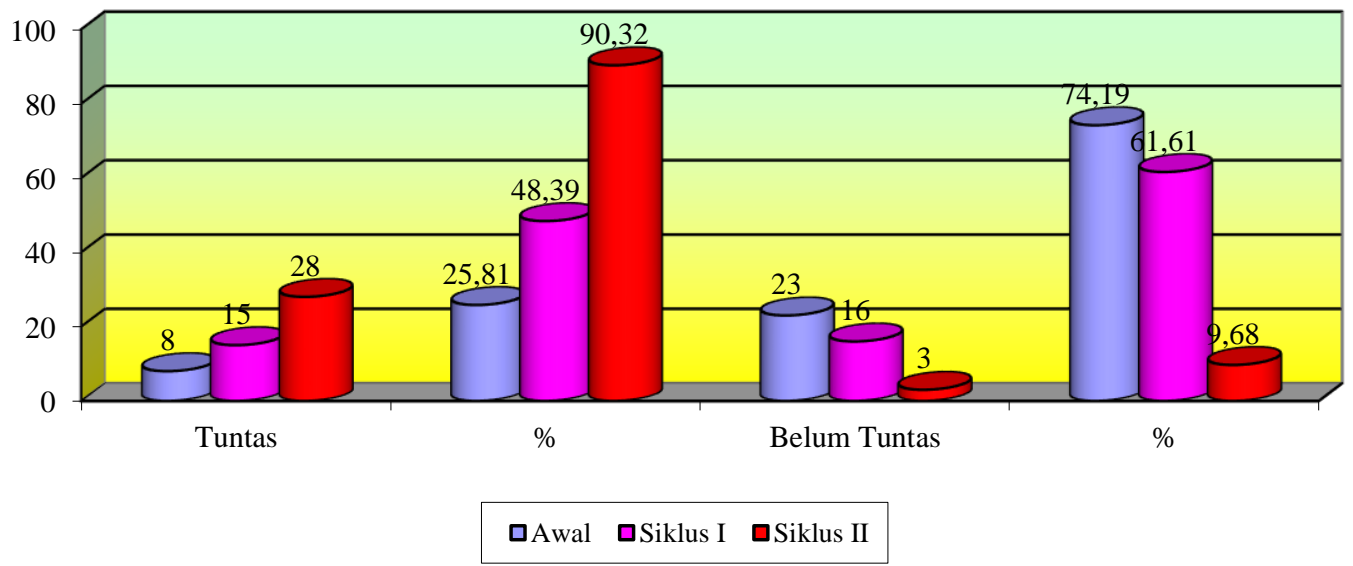

Grafik 1. Peningkatan Ketuntasan Belajar Siswa pada Kondisi Awal, Siklus I, dan Siklus II 
Peningkatan nilai rata-rata hasil belajar siswa dalam bentuk grafik sebagaimana Grafik 2. di bawah ini:

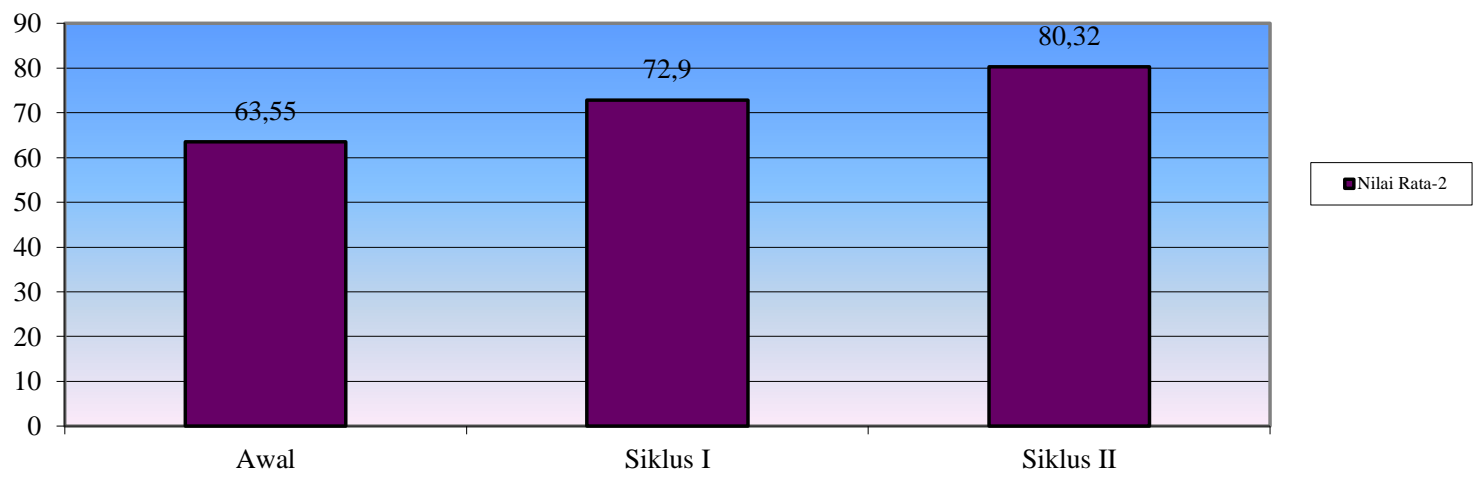

Grafik 2. Peningkatan Nilai Rata-Rata Belajar Siswa Pada Kondisi Awal, Siklus I, dan Siklus II

Dari hasil observasi mengenai hasil dan ketuntasan belajar siswa tersebut dapat dikatakan bahwa proses perbaikan pembelajaran dinyatakan berhasil karena peningkatan hasil dan ketuntasan belajar siswa mencapai angka 90,32\% dari $85 \%$ batasan minimal yang telah ditentukan pada kriteria keberhasilan proses perbaikan pembelajaran. Atas dasar pertimbangan sebagaimana diuraikan di atas, maka peneliti dan observer memutuskan bahwa kegiatan perbaikan pembelajaran diakhiri pada siklus II dan dapat disimpulkan bahwa penggunaan model pembelajaran tipe Think Talk Write (TTW) pada pembelajaran bahasa Inggris menunjukkan peningkatan yang signifikan terhadap hasil proses pembelajaran.

\section{Pembahasan}

Berdasarkan hasil pelaksanaan tindakan pada siklus I dan II ternyata terjadi peningkatan hasil belajar bahasa Inggris siswa kelas VII B SMPN 1 Sumowono tahun pelajaran 2018/2019 melalui penerapan model pembelajaran kooperatif tipe Think Talk Write (TTW). Menurut Ansari (2004:36), strategi TTW adalah suatu pembelajaran untuk melatih keterampilan siswa dalam menalar. Pembelajaran ini pada dasarnya dibangun melalui berpikir, berbicara, dan menulis. Alur kemajuan TTW dimulai dari keterlibatan siswa dalam berpikir atau berdialog dengan dirinya sendiri setelah proses membaca. Selanjutnya berdiskusi dan membagi ide (sharing) dengan temannya sebelum menulis dan akhirnya melalui diskusi, siswa dapat menuliskan kembali hasil pemikirannya tersebut.

Tujuan pengajaran merupakan kemampuan yang diharapkan dimiliki oleh siswa setelah menyelesaikan pengalaman belajarnya, tujuan pengajaran adalah tujuan yang menggambarkan pengetahuan, keterampilan, dan sikap yang harus dimiliki oleh siswa sebagai akibat dari hasil pengajaran yang dinyatakan dalam bentuk tingkah laku (behavior) yang dapat diamati dan diukur. Oleh karenanya menurut Arikunto dalam merumuskan tujuan intruksional harus diusahakan agar tampak bahwa setelah anak yang meliputi kemampuan intelektual, sikap/minat maupun keterampilan. Arikunto (Purwanto, 2011:45).

Pembelajaran TTW diperkenalkan oleh Huinker. Pembelajaran ini menekankan perlunya peserta didik mengkomunikasikan hasil pemikirannya. Pembelajaran ini diawali dengan peserta didik membaca dan mencoba memahami masalah yang diberikan, kemudian diikuti dengan peserta didik mengkomunikasikan selesaian yang diperolehnya, dan akhirnya melalui diskusi serta negosiasi, peserta didik dapat menuliskan kembali hasil pemikirannya tersebut (Soedjoko 2006:6). Dari pendapat tersebut dapat dijelaskan bahwa pembelajaran TTW membangun secara tepat untuk berpikir, merefleksi, dan mengorganisasikan ide-ide serta mengetes ide tersebut sebelum siswa diminta untuk menulis. 
Pembelajaran TTW akan membangun pemikiran, refleksi, dan untuk mengorganisasi gagasan serta menguji coba (menelaah) gagasan-gagasan itu sebelum siswa menuliskannya dengan segera. Tahap-tahap penerapan pembelajaran TTW mempertimbangkan pengamatan hasil diskusi. Ide-ide dari siswa dipikirkan dan didiskusikan yang menunjukkan kemampuan siswa untuk berbicara dan berbagi gagasan satu sama lain untuk selanjutnya dituliskan (NCTM dalam Ratna 2007:14). Pembelajaran TTW adalah pembelajaran yang memfasilitasi latihan berbahasa secara lisan dan menulis bahasa tersebut dengan lancar. Pembelajaran TTW didasarkan pada pemahaman bahwa belajar adalah sebuah perilaku sosial. Pembelajaran TTW mendorong siswa untuk berpikir, berbicara, dan kemudian menuliskan berkenaan dengan suatu topik.

Tujuan penerapan metode pembelajaran hakikatnya adalah memberikan situasi yang kondusif agar terjadi proses belajar pada diri siswa. Proses belajar yang terjadi haruslah dalam suasana proses belajar aktif melalui pemanfaatkan sumber belajar guna mencapai tujuan belajar yang telah ditetapkan sebelumnya. Hal ini sesuai dengan pendapat Elliot dan Yuzar (Muslim Ibrahim, 2001:21) yang menyatakan bahwa dalam penerapan Think Talk Write (TTW), siswa sebagai anggota kelompok bertanggung jawab untuk mempelajari, menguasai bagian tertentu bahan yang diberikan. Siswa kemudian menjelaskan pada anggota kelompoknya. Dengan demikian terdapat rasa saling membutuhkan dan harus bekerjasama secara kooperatif untuk mempelajari materi yang ditugaskan, baik dalam kelompok ahli maupun kelompok asal.

Berdasarkan hasil observasi yang dilakukan pada siklus I, dapat diketahui bahwa model pembelajaran kooperatif tipe Think Talk Write (TTW) telah terbukti dapat meningkatkan proses dan kegiatan pembelajaran bahasa Inggris. Cooperatif Learning dapat mendorong tumbuhnya tanggung jawab social dan individual siswa, berkembangnya sikap ketergantungan yang positif, meningkatkan gairah belajar, kekompakan dalam kelompok, serta cooperatif learning mampu mendorong tumbuhnya sikap kesetiakawanan dan keterbukaan di antara kelompok. Pada siklus II pembelajaran dengan model kooperatif Think Talk Write (TTW) telah efektif dan memberikan kontribusi yang positif pada peningkatan hasil belajar siswa yang diterapkan pada kelompok-kelompok kecil yang keanggotaannya heterogen, sehingga guru lebih mudah memotivasi siswa dan memberikan bimbingan yang maksimal serta mengontrol perkembangan prestasi belajar siswa dengan baik. Kontribusi pembelajaran dengan metode tipe Think Talk Write (TTW) selama penelitian menunjukkan bahwa semangat siswa semakin meningkat terbukti dengan peningkatan hasil belajar dari siklus II dibanding tes awal dan siklus I, siswa sangat antusias dan mengambil andil yang besar dalam mengikuti pelajaran bahasa Inggris, dengan setting kelompok-kelompok kecil siswa merasa lebih senang belajar, sehingga siswasiswa merasakan dampak yang positif dan bermanfaat dalam hal belajar terutama dalam berdiskusi yaitu hal-hal atau pelajaran yang sulit dapat dipecahkan dengan mudah secara bersama-sama dalam kelompok-kelompok kecil yang dibentuk, serta ada masukan maupun tambahan dari kelompok lain, sehingga menambah wawasan pengetahuan dari kelompok yang masih kurang mendalam dalam memahami pelajaran yang sedang dibahas dalam diskusi kelompok. Siswa mendapatkan kesempatan yang sama untuk berdiskusi, untuk menyampaikan pendapat-pendapat atau gagasan-gagasan sesuai dengan pengalaman atau pengetahuan yang dimiliki sehingga saling melengkapi satu sama lain, dengan pembelajaran model tipe Think Talk Write (TTW) juga mengajarkan kepada siswa siswi untuk menjadi seorang pemimpin untuk memimpin kelompok-kelompok kecil dan menjadi ketua dalam kelompok serta menjadi narasumber bagi teman yang lain, sehingga siswa tidak hanya menerima informasi, tetapi juga mengkonstruksi pengetahuan (construction of knowledge).

Model Think Talk Write (TTW) merupakan salah satu metode belajar yang menempatkan siswa sebagai subyek aktif. Siswa dituntut memiliki tanggung jawab besar dalam proses pembelajaran. Siswa sejak awal diberikan perspektif mengenai tujuan pembelajaran, target, proses, dan dinamika yang akan dijalaninya. Model Think Talk Write (TTW) melalui proses eksploratif dan diskusi yang intensif, memungkinkan proses penguasaan materi yang lebih mendalam dan luas. Sesuatu yang tidak mungkin didapat jika hanya belajar sendiri. 
Potensi yang lebih besar untuk memunculkan proses analisis daripada hanya sekedar narasi sederhana. Konsekuensi dari model Think Talk Write (TTW) ini adalah dibutuhkan keseriusan dan kerja keras dari siswa untuk mengeksplorasi bahan-bahan pelajaran dan aktif melakukan diskusi sesuai tema yang direncanakan. Kemudahan akses internet, perpustakaan dan bukubuku sebagai referensi, sekarang ini sangat mendukung untuk mendapatkan materi belajar yang bermutu. Selain itu juga peran penting dari guru, yang memantik dan menjaga proses Think Talk Write (TTW) tersebut tetap hidup dan dinamis. Model Think Talk Write (TTW) menjadikan proses pembelajaran menjadi dinamis dan menuntut kita selalu berfikir kritis, analitis dan sitesis. Ibaratnya kita adalah api yang dinyalakan untuk mengobarkan semangat mengkaji ilmu, bukan tong tempat menampung sampah. Dengan hasil yang dicapai tersebut maka menunjukkan bahwa model Think Talk Write (TTW) tepat digunakan sebagai model pembelajaran bahasa Inggris di kelas VII B SMPN 1 Sumowono.

Berdasarkan pembahasan hasil tindakan siklus I dan II, maka dapat dikatakan bahwa hipotesis penelitian tindakan pengunaan model pembelajaran kooperatif tipe Think Talk Write (TTW) pada subtema Introduce Myself dapat terbukti meningkatkan keaktifan dan hasil belajar bahasa Inggris siswa kelas VII B SMPN 1 Sumowono.

\section{KESIMPULAN}

Berdasarkan hasil analisis data dan temuan yang diperoleh pada siklus I, dan II dapat ditarik kesimpulan sebagai berikut: (1) Pembelajaran bahasa Inggris dengan menerapkan model pembelajaran Think Talk Write telah mampu mengubah sikap dan perilaku siswa dari perilaku negatif berubah menjadi positif. Contoh perubahannya seperti siswa yang semula kurang siap, kurang bersemangat, dan kurang aktif dalam mengikuti pembelajaran menjadi siap, bersemangat, senang, dan menikmati pembelajaran. Siswa juga tampak lebih aktif dalam berpikir (think), berdiskusi antar kelompok (talk), dan lebih aktif dalam menulis materi tentang Introduce Myself (write). Selain itu, siswa juga lebih berani bertanya kepada peneliti jika merasa ada kesulitan dalam menulis materi tentang Introduce Myself serta lebih berani untuk menjawab pertanyaan dan memberikan komentar; (2) Penggunaan model pembelajaran Think Talk Write pada pembelajaran bahasa Inggris subtema Introduce Myself terbukti mampu meningkatkan keaktifan belajar dari angka 45,16\% atau 14 siswa pada studi awal menjadi 74,19\% atau 23 siswa pada siklus pertama, meningkat menjadi 93,55\% atau 29 siswa pada siklus kedua. Ketuntasan belajar sudah mencapai $85 \%$ dari jumlah seluruh siswa sesuai dengan indikator dan kriteria keberhasilan yang telah ditentukan. (3) Penggunaan model pembelajaran Think Talk Write pada pembelajaran bahasa Inggris subtema Introduce Myself terbukti mampu meningkatkan hasil dan ketuntasan belajar siswa. Hal tersebut dibuktikan dengan kenaikan hasil belajar siswa dari rata-rata pada temuan awal hanya 63,55 naik menjadi 72,90 pada siklus pertama, dan 80,32 pada siklus kedua., dengan tingkat ketuntasan belajar sebanyak 8 siswa atau $25,81 \%$ pada studi awal, 15 siswa atau $48,39 \%$ pada siklus pertama, 28 siswa atau $90,32 \%$ pada siklus kedua.

\section{DAFTAR PUSTAKA}

Ambari, Desy, dkk. (2012). Pengaruh Model Pembelajaran Think Talk Write Berbantuan Media Gambar Terhadap Hasil Belajar IPA Siswa Kelas IV Gugus 1 Kecamatan Tegal Lalang. Skripsi. Universitas Pendidikan Ganesha Singaraja.

Ansari, Bansu. Irianto. (2004). Menumbuhkan Kemampuan Pemahaman dan Komunikasi Matematik Siswa SMU Melalui Strategi Think-Talk Write. Disertasi Tak Diterbitkan. Bandung: Progam Pascasarjana UPI Bandung.

Arikunto, Suharsimi. (2006). Prosedur Penelitian Suatu Pendekatan Edisi Revisi VI. Jakarta: Rineka Cipta.

Arikunto, Suharsimi. (2009). Dasar-Dasar Evaluasi Pendidikan. Jakarta: Bumi Aksara. 
Ayu, Dewa, dkk. (2014). Pengaruh Penerapan Model Pembelajaran Kooperatif Tipe TTW Terhadap Hasil Belajar Bahasa Indonesia.e-Journal Mimbar PGSD Universitas Pendidikan Ganesha Jurusan PGSD.

Ratna, Aprilia Tri. (2007). Komunikasi Matematik Siswa Kelas VII SMPN 30 Semarang Tahun Pelajaran 2006/2007 dalam Pembelajaran dengan Strategi Think-Talk-Write (TTW) pada Pokok Bahasan Segiempa. Skripsi. Semarang: FMIPA Unnes.

Soedjoko, Edy. (2006). Strategi "Think-Talk-Write (TTW) dengan Tugas-Tugas Membaca untuk Meningkatkan Kemampuan Pemecahan Masalah Matematika. FMIPA: Unnes.

Zulkarnaini. (2011). "Model Kooperatif Tipe Think Talk Write (TTW) untuk Meningkatkan Kemampuan Menulis Karangan Deskripsi dan Berpikir Kritis”. Jurnal Penelitian Pendidikan. 